NACHRICHTEN

\section{Research for sustainability - the fona network goes interna- tional}

Visit the new English version of the network platform

\section{http://www.fona.de}

for information about the activities in the German 800-million-euro-funding programme "Research for Sustainability".

fona is an initiative of the German Federal Ministry of Education and Research (BMBF) and was conceived as an open platform for all actors in the field of research for sustainability.

The aims of fona are a wider use of sustainability research by bundling and documenting research activities as well as constructing a network of actors by linking actors with research contents and the latest information.

Registered actors can present their service spectrum.

The fona network lives on the active participation of the registered actors who now can present their range of services and specific activities in research, development and education to those interested from society, economy, and further education at http://www.fona.de.

\section{Registration form:}

http://www.fona.de/eng/Registration

Additionally, actors can publish press releases or information on activities such as events, fairs or workshops. They can also provide references to publications and subject-relevant links.

(VDI Press Release)

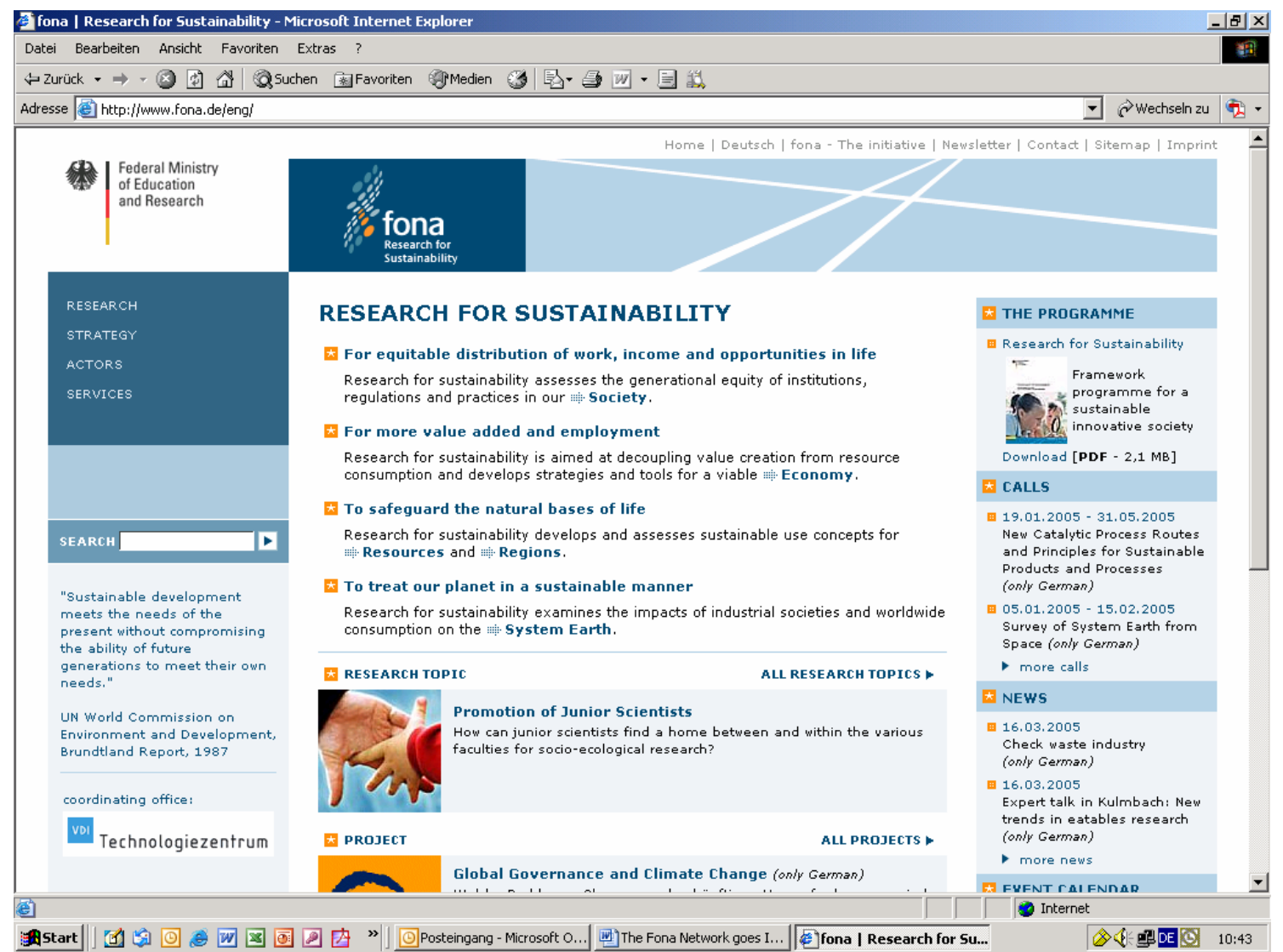

